$\mathrm{Oz}$

Volume 9

Article 8

$1-1-1987$

Being in Place

Bob Burnham

Follow this and additional works at: https://newprairiepress.org/oz

cc) (i) $\Theta$

This work is licensed under a Creative Commons Attribution-Noncommercial-No Derivative Works 4.0 License.

Recommended Citation

Burnham, Bob (1987) "Being in Place," Oz: Vol. 9. https://doi.org/10.4148/2378-5853.1137

This Article is brought to you for free and open access by New Prairie Press. It has been accepted for inclusion in Oz by an authorized administrator of New Prairie Press. For more information, please contact cads@k-state.edu. 


\section{Being in Place}

Bob Burnham

Houses are pragmatic responses to be ing somewhere. They provide shelter from the elements, security for the body and possessions, and a physical expression of social identity. They are also one means by which people make connections to concepts of place, time and self

This design for a studio house explores several themes which have been represented repeatedly in the architecture of the house since men began fashioning rather than finding dwellings. They include:

- a centrally placed quiet garden, a symbol of inner peace.

- the cosmic wheel or mandala, a symbol of centering and balance in the cosmos or the self.

the use of human characteristics in the organization, shaping or decoration of the house.

a dominant expression of shelter in the roof form.

connection to the sky, particularly the sun which is our primal source of energy through the use of a diagrammed vertical axis.

The house was intended for a corner lot in a century-old neighborhood in Manhattan, Kansas. The neighborhood consists of modest one- to two-story houses with little in the way of pretentious styling. Some of them are painfully small, toylike, if not intentional miniatures. Several nearby houses are simple one-story boxes with lid-like 32 hip roofs and face-like front elevations

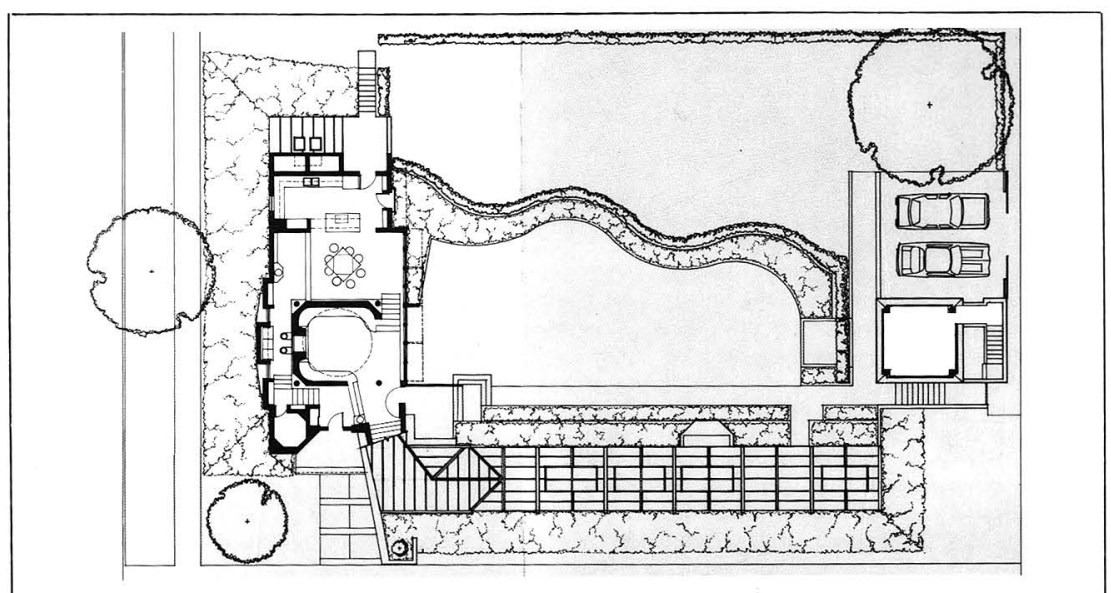

Plan, upper level.

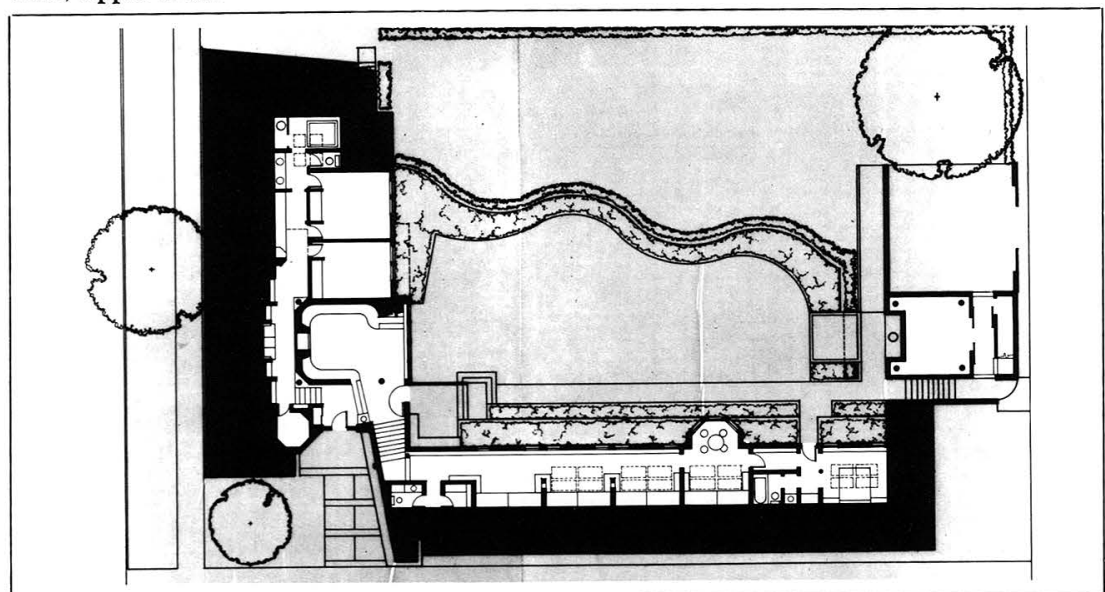

Plan, lower level.

consisting of a single door and two windows.

The lot employed for this study was occupied by a small house which had burned and left a black hole where its basement had been. The proposed house conserves and repairs the broken site by enlarging the derelict basement and transforming it into a sunken garden. The house wraps around this garden making and protecting a quiet center.

The house is settled into the ground and bermed on the street sides (north and west) to help achieve thermal and acoustical buffering of the spaces within. It is a half-dug house like many of the most primitive of dwellings which were

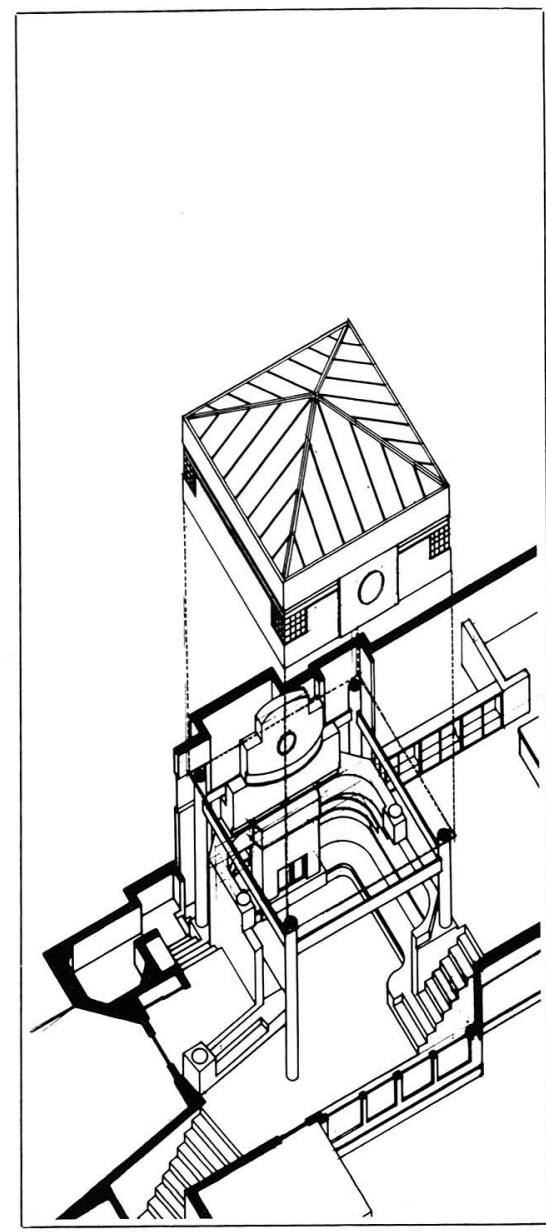

Exploded axonometric of sitting-living room created by excavating a shallow pit for the floor and constructing walls or a roof in part from the resulting debris.

The house is organized in three blocks. The main living quarters occupy the north side of the garden, the studio space and a guest room are on the west side of the lot, and a storage building supporting an open air pavilion is on the 

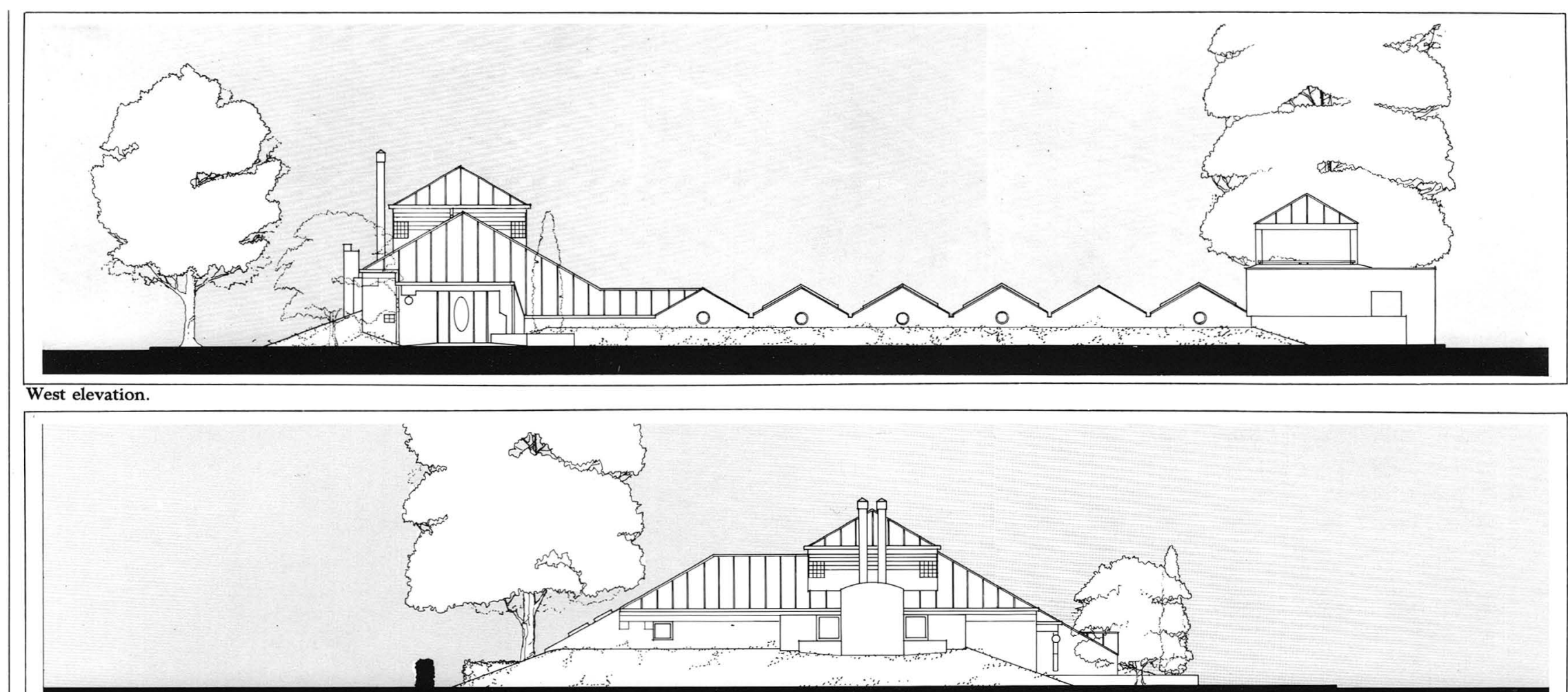

North elevation.

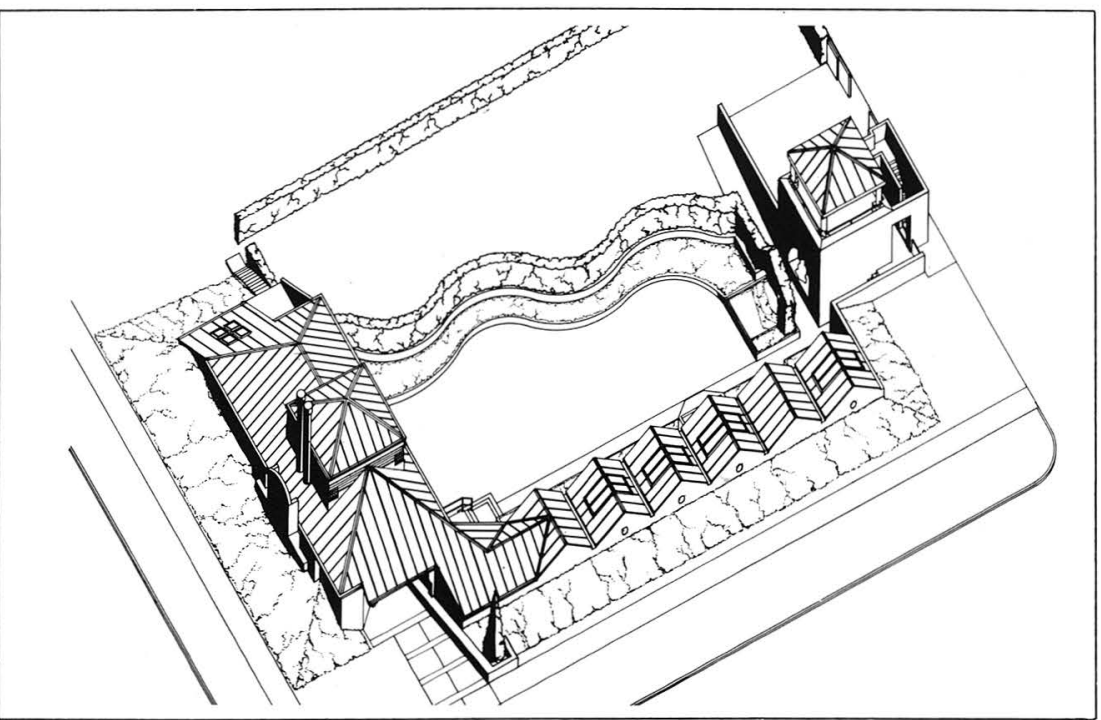

Axonometric from Northwest.

south side of the garden. The dominant space in the house is a sitting room which occupies the joint between the living and the studio spaces. It takes the form of a meditating cosmic being, a symbol of the transcendent self, seated under a simple pavilion.

The pavilion has a domed ceiling with a simple mandala painted on it. This space is the built center of a reconstructed place on the corner of two streets in a small Midwestern town. It is a centering space in time connecting the quest for balance in self and eternal peace.

Occupants of this room sit on the lap of the greater self. The fireplace is located on it's axis and, together with

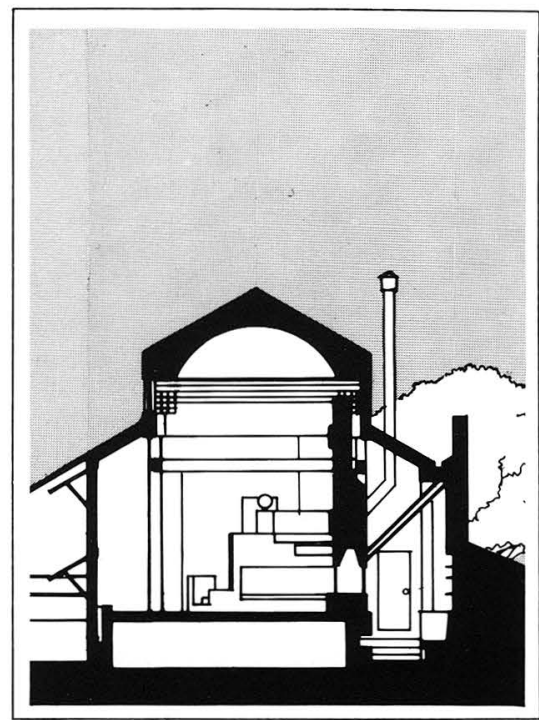

Cross section

the flues, diagrams the connection between the little internal fire and the universal sun.

In front of the cosmic being across the garden and beyond a small pool is another image of the greater self: a lifesize statue of a seated person in meditation. This figure of containment is seen through an eye or circular opening in a hedge wall. The most private rooms in this house, bedrooms and bathroom, are approached by a corridor which is in back of or behind the cosmic being.

The garden is turfed and finely kept. It is tiered on east and west sides. The righthand side (west) is rigidly organized in neat geometrically patterned flowers beds. The leftband side is curved and planted with herbs in random pattterns climbing to a hedge wall which separates the quiet center from a working fringe of vegetable garden.

Some of the edges of this house process faces. The north elevation, which confronts a major neighborhood street, presents a neutral composed face to the world - a dignified persona. The east elevation of studio wing which faces the garden - the inner world of this place - displays a series of faces expressing a full range of emotions.

If this house is familiar to many people, it is because of the use of these enduring themes. It is a conservative house which tries to speak in ancient ways about being at home in place. 